\title{
Sources of black Sigatoka resistance in wild banana diploids
}

\author{
Fernanda dos Santos Nascimento ${ }^{1}$, Yan Moreira Sousa ${ }^{2}$, Anelita de Jesus Rocha ${ }^{3}$, \\ Claudia Fortes Ferreira ${ }^{4}$, Fernando Haddad ${ }^{4}$, Edson Perito Amorim ${ }^{4}$
}

\begin{abstract}
Black Sigatoka (black leaf streak disease) is caused by the fungus Mycosphaerella fijiensis Morelet. This phytopathogen colonizes banana leaves, resulting in reduced photosynthesis and decreased productivity. Fungicide applications are useful to control black Sigatoka; however, they increase production costs and can have adverse environmental and health impacts. The cultivation of resistant cultivars is regarded as a more economically viable option. The objective of this study was to perform diploid phenotyping in a set of wild banana accessions to identify resistant genotypes. A total of 31 accessions ( 30 with $\mathrm{AA}$ genome and one with $\mathrm{AB}$ genome) were phenotyped based on the presence of disease symptoms using a scoring scale. The area under the disease progress curve (AUDPC), the disease severity index (DI), and the disease severity increase index (DII) were estimated. The DII variable proved to be efficient in identifying banana accessions with black Sigatoka resistance. Likewise, the selection index for ranking accessions with moderate black Sigatoka resistance allowed us to identify those genotypes with the highest quantitative resistance. Five diploid accessions (Krasan Saichon, Zebrina, Birmanie, N $^{\circ} 118$, and Tuu Gia) were found to be resistant to this fungal disease; eight accessions (PA Rayong, Pisang Cici, Malaccensis 1, 028003-01, Microcarpa, Pisang Lidi, Lilin, and Malbut) were moderately resistant.
\end{abstract}

Index terms: Phenotyping; Musa spp.; Mycosphaerella fijiensis.

\section{Fontes de resistência à Sigatoka-negra entre diploides selvagens de bananeira}

Corresponding author: edson.amorim@embrapa.br

Received: April 06, 2020 Accepted: May 21, 2020

Copyright: All the contents of this journal, except where otherwise noted, is licensed under a Creative Commons Attribution License.
Resumo - A Sigatoka-negra, causada pelo fungo Mycosphaerella fijiensis Morelat, é uma doença que afeta as folhas da bananeira, reduzindo a fotossíntese e ocasionando queda na produtividade. O controle baseia-se no uso de fungicidas; no entanto, essa prática eleva o custo de produção e pode causar impactos ambientais e na saúde. O plantio de cultivares resistentes mostra-se mais viável economicamente. $\mathrm{O}$ objetivo deste estudo foi realizar a fenotipagem de diploides, visando à identificação de genótipos resistentes. Foram fenotipados 31 acessos (30 com genoma AA e um com genoma $\mathrm{AB}$ ), a partir da expressão dos sintomas da doença, por meio de escala de notas. Estimaramse a área abaixo da curva do progresso da doença (AACPD), o índice de severidade da doença (ID) e o índice de aumento da severidade da doença (AID). A variável AID mostrou-se eficiente na identificação de acessos de bananeira com resistência à Sigatoka-negra. O índice de seleção para o ranqueamento de acessos, com moderada resistência à Sigatoka-negra, permitiu identificar os genótipos com maior resistência quantitativa. Cinco acessos diploides foram resistentes (Krasan Saichon, Zebrina, Birmanie, $\mathrm{N}^{\circ} 118$ e Tuu Gia), e oito moderadamente resistentes (PA Rayong, Pisang Cici, Malaccensis 1, 028003-01, Microcarpa, Pisang Lidi, Lilin e Malbut).

Termos para indexação: Fenotipagem; Musa spp.; Mycosphaerella fijiensis.

\footnotetext{
${ }^{1}$ Biologist, Master Student in Plant Genetic Resources, Universidade Federal do Recôncavo da Bahia (UFRB), Cruz das Almas-Bahia, Brazil. E-mail: fee1.20@hotmail.com ${ }^{\text {(ORCID: 0000-0003-3033-1604) }}$

${ }^{2}$ Biology student, Universidade Federal do Recôncavo da Bahia (UFRB), Cruz das Almas-Bahia, Brasil-. E-mail: yansousa16@gmail.com (ORCID: 0000-0001-9215-7694)

${ }^{3}$ Agronomist, PhD student, Universidade Estadual de Feira de Santana (UEFS), Feira de Santana-Bahia, Brazil. E-mail: anelitarocha@gmail.

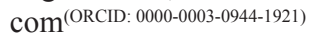

${ }^{4}$ Agronomist, PhD., Researcher at Embrapa Mandioca e Fruticultura, Cruz das Almas-Bahia, Brazil. E-mail: claudia.ferreira@embrapa.br ${ }^{\text {(ORCID: }}$

0000-0001-5476-2236); fernando.haddad@embrapa.br (ORCID 0000-0003-0332-3270); edson.amorim@embrapa.br (ORCID 0000-0001-9086-7385).
} 


\section{Introduction}

Bananas and plantains are essential components of the human diet for millions of people in tropical and subtropical regions, also impacting on social and economic issues (WEBER et al., 2017; ALAKONYA et al., 2018). Like many other crops, banana trees are exposed to several phytosanitary problems, which may affect their roots, rhizomes, pseudostems, leaves, and fruits (AMORIM et al., 2013).

Significant losses in bananas and plantains production were assigned to black Sigatoka, a disease caused by the fungus Mycosphaerella fijiensis M. Morelet (asexual phase: Pseudocercospora fijiensis (M. Morelet). This fungus was first described in 1963, in the Fiji Islands (CROUS et al., 2003), and in Brazil, the first reports date from 1998, when it was identified in plantations around the cities of Tabatinga and Benjamin Constant, in the State of Amazonas, close to the border with Colombia and Peru (GASPAROTTO et al., 2006). M. fijiensis propagation occurs through air-disseminated conidia, which are asexual spores, and through sexual ascospores (CHURCHILL, 2011; ONYLO et al., 2018).

Black Sigatoka is usually controlled using contact and systemic fungicides. The application of these chemicals results in huge increases in production costs for the banana industry worldwide, which were estimated in several hundred millions of dollars a year (CHURCHILL, 2011; DIAS-TRUJILLO et al., 2018). Besides, these pesticides may induce pathogen resistance, impact the environment, and compromise farmers' and consumers' health (BURGOS-CANUL et al., 2019). In this sense, biological control is emerging as an alternative to minimize these disadvantages; however, some limiting factors (e. g., inefficient biological agents, high production costs, inadequate techniques) make biological control an incipient practice yet (JIMENEZ et al., 2007).

According to previous data, M. fijiensis resistance is associated with a recessive allele called $b s l$ and two independent alleles with additive effects known as $b s r 2$ and $b s r 3$ (ORTIZ; VUYLSTEKE, 1994). Also, intralocus interaction in $b s l$ was reported, which seems to be associated with the onset of early leaf signs and with the intraloci interaction in the $b s r$ loci, which influences the disease progression (CRAENEN; ORTIZ, 1997).

The use of cultivars with quantitative resistance to black Sigatoka is regarded as a sustainable alternative for the banana and plantain agribusiness; these cultivars can integrate management systems in which practices such as biological control and sanitary defoliation have the potential to reduce inoculum sources. Some banana breeding programs have relied on black Sigatoka resistance found in wild Musa species, including $M$. acuminata subsp. burmanicca, M. acuminata subsp. malaccensis, and M. acuminata subsp. siamea, also in diploid cultivars (JONES et al., 2000).

To develop disease-resistant cultivars, since 1982, an Embrapa breeding program has been crossing improved diploids resistant to M. fijiensis, Mycosphaerella musae, and Fusarium oxysporum f. sp. cubense race 1 with susceptible triploid or tetraploid commercial cultivars (AMORIM et al., 2013). Based on this strategy, eleven tetraploid hybrids were developed and recommended to Brazilian farmers.

The development of improved diploids is a routine activity at Embrapa; this institution annually generates several hybrids resistant to yellow Sigatoka and Fusarium wilt race 1 . Some of them are also resistant to black Sigatoka and tolerant to rhizome borers and nematodes and show other relevant agronomic traits. All this work is integrated into a dynamic process, where new, improved diploids with superior characteristics are introduced in the crossing routines, while others are excluded for technical reasons (AMORIM et al., 2013). Besides, it is also important to have improved diploids with different genetic backgrounds to avoid narrowing the genetic base of commercial banana germplasm.

In this context, the objective of this study was to identify wild banana diploid accessions resistant to $M$. fijiensis in order to; these selected genotypes may be valuable to develop new, improved diploids to be used in future crosses.

\section{Material and methods}

The experiment was conducted at the Embrapa Mandioca e Fruticultura experimental area, located in Cruz das Almas, Bahia state, Brazil (12 40'19”'S, 3906'22'”W, $220 \mathrm{~m}$ altitude). In this tropical region, the climate is hot and wet (Aw to Am, Köppen classification), with an annual average temperature of $24.5^{\circ} \mathrm{C}$, a relative humidity of $80 \%$, and an average annual rainfall of $1,250 \mathrm{~mm}$ (AGRITEMPO, 2018).

This study evaluated 31 banana diploid accessions belonging to Embrapa banana and plantain germplasm collection; all were AA-genome accessions, except for genotype IAC 1 (AB genome) (Table 1). This collection is represented by four plants per accession (arranged in 2.0 $\mathrm{m}$-separated rows, with a spacing of $1.7 \mathrm{~m}$ between plants), irrigated by a micro-sprinkler system, as necessary. This management is intended to prevent plant stress due to water deficit, in a region typically subjected to water scarcity periods. 
Table 1. Banana diploid accessions belonging to the Embrapa banana and plantain germplasm collection phenotyped in the presence of black Sigatoka. Cruz das Almas, BA, Embrapa 2020.

\begin{tabular}{|c|c|}
\hline Genotype & Subgroup/ Subespecie \\
\hline Pisang Jari Buaya & Pisang Jari Buaya \\
\hline Pisang Lillin & Pisang Lillin \\
\hline 028003-01 & Tuu Gia x Calcutta 4 \\
\hline M53 & (Kedat x Samoa) (Paka x Samoa) \\
\hline Pisang Jaran & ssp. burmannica \\
\hline Malbut & _- \\
\hline $\mathrm{N}^{\mathrm{o}} 118$ & _- \\
\hline PA Rayong & ssp. Siamea \\
\hline Zebrina & ssp. Zebrina \\
\hline Buitenzorg & ssp. Zebrina \\
\hline Birmanie & _- \\
\hline Akondro Mainty & _ \\
\hline Pisang Lidi & - \\
\hline Khai Nai On & - \\
\hline Microcarpa & ssp. Microcarpa \\
\hline Pisang Berlin & - \\
\hline Khi Maeo & - \\
\hline Mambee Thu & ssp. Banksii \\
\hline Niyarma Yik & ssp. Banksii \\
\hline Malaccensis 1 & ssp. Malaccensis \\
\hline Malaccensis 2 & ssp. Malaccensis \\
\hline Pisang Tongat & ssp. Errans \\
\hline Pisang Pipit & - \\
\hline SF-751 & _- \\
\hline Pisang Rojo Uter & - \\
\hline Tuu Gia & - \\
\hline Krasan Saichon & - \\
\hline Tjau Lagada & - \\
\hline Tong Dok Mak & - \\
\hline Pisang Cici & ssp. Malaccensis \\
\hline IAC 1 & Musa acuminata x Musa balbisiana \\
\hline
\end{tabular}

_: Unclassified in Subgroup or Subspecies.

The accessions were evaluated for black Sigatoka resistance/susceptibility using a scoring scale (1 to 6) based on the percentage of the leaf area showing disease signs, as proposed by Stover (1972) and later modified by Gauhl (1989): (1) up to $1 \%$; (2) 1 to $5 \%$; (3) 6 to $15 \%$; (4) 16 to $33 \%$; (5) 34 to $50 \%$; and (6) 51 to $100 \%$ of damaged leaf area.
The evaluations started twelve months after planting by visualizing black Sigatoka signs on all leaves until their complete senescence, totaling 26 evaluations from July 2017 to July 2018. All fully-developed leaves were evaluated in a variable number depending on the leaf formation rate of each accession. Three plants per accession were evaluated with 15-day intervals.

The scores obtained were used to calculate a disease severity index DI (\%) for each accession, based on the formula described by McKinney (1923):

$$
D I(\%)=\left[\frac{\left.\sum \text { disease score } x \text { number of plants with a given disease score }\right) x 100}{\text { number of plants evaluated per plot } x \text { highest score }}\right.
$$


The area under the disease progress curve (AUDPC) was estimated according to the formula proposed by Madden et al. (2007):

$$
A U D P C=\frac{\sum n-1 n[(D I 1+D I 2)]}{2} x(T 2-T 1)
$$

where $n$ is the number of evaluations, $D I$ is the disease severity index, and $(T 2-T 1)$ is the time interval between two consecutive evaluations.

The AUDPC was standardized for the number of evaluations conducted until the bunches were harvested, considering that the number of leaves formed by banana plants of different accessions was variable.

Besides, the disease severity increase index (DII, $\%$ ) was estimated from the sum of the obtained DIs at each evaluation time, using the following formula:

$$
D H=\frac{\sum D I}{n} \times 100
$$

where $n$ is associated with the number of evaluations.
Based on the AUDPC, DI, and DII, two heatmaps were created; one of them considered AUDPC and DI, the other one combined three variables, using the average Euclidean distance and the $k$-means method to group the accessions, and the cutoff point criterion proposed by Krzanowski and Lai (1988). A heatmap is a graphical tool that aids in the interpretation of data sets.

The statistical packages used for the analyses were devtools (WICKHAM; CHANG, 2017), NbClust (CHARRAD et al., 2014), and gplots (WARNES et al., 2015), all executed in the R software.

The Scott-Knott clustering test was used to rank the genotypes classified as moderately resistant to black Sigatoka, and a selection index (SI) was estimated; each group formed in the Scott-Knott test received weight 10. The variable AUDPC formed four groups: group "a" had weight 40; group "b," 30; group "c," 20; and group "d," 10. The variable mean DI formed three groups, "a," "b," and "c," with weights 40, 30, and 10, respectively. Lastly, the variable DII formed groups "a," "b," "c," and "d," with weights of $40,30,20$, and 10 , respectively. The SI index was obtained using this formula: $\mathrm{SI}=\Sigma(\mathrm{AUDPC})$ $+(\mathrm{DI})+(\mathrm{DII}(\%))$. A hypothetical numerical example is presented in the Table 2:

Table 2. Selection index to rank genotypes classified as moderately resistant to black Sigatoka. Cruz das Almas, BA, Embrapa 2020.

\begin{tabular}{cccrc}
\hline Genotypes & AUDPC & DI & DII $(\%)$ & Selection index (SI) \\
\hline Gen. 1 & $50 \mathrm{~b}$ & $70 \mathrm{a}$ & $10 \mathrm{~b}$ & 100 \\
Gen. 2 & $70 \mathrm{a}$ & $70 \mathrm{a}$ & $3 \mathrm{~d}$ & 90 \\
Gen. 3 & $30 \mathrm{c}$ & $50 \mathrm{~b}$ & $18 \mathrm{a}$ & 60 \\
Gen. 4 & $10 \mathrm{~d}$ & $15 \mathrm{c}$ & $7 \mathrm{c}$ & 50 \\
\hline
\end{tabular}

Means followed by the same letter within columns belong to the same group according to the Scott-Knott test. *Group weight: a (40); b (30); c (20); d (10).

The accessions with selection indexes decreased by $60 \%$ were considered those with better quantitative resistance, thus obtaining a cutoff score of 70 . Genotypes with values $\leq 70$ would be indicated for the breeding program.

\section{Results and discussion}

Heatmap analyses were performed based on the two selection strategies, (AUDPC + DI and AUDPC + DI + DII (Figure 1). Green shades are associated with genetic resistance levels (light green indicates high resistance), while red shades indicate susceptibility levels (light red indicates high susceptibility). AUDPC and DI form a group, while DII remains isolated (Figure 1B), indicating that the last one is a relevant selection parameter. The heatmap is an easy- to- interpret analysis when compared to classic grouping methods based on dendrograms (REBOUÇAS et al., 2018).

The number of genotypes and specimens in each cluster was variable, depending on the selection parameters considered (Figure 1A and 1B). When DII was included in the analysis, more accessions were considered moderately resistant to black Sigatoka (21 genotypes) compared to the cluster formed considering only AUDPC and DI. Thus, better efficiency in genotype discrimination into resistant (GI), moderately resistant (GII), and susceptible (GIII) groups was attained when considering the variable DII, because this variable describes the disease progression over time, which may be a relevant point in our experimental setting, as some materials showed signs within a short period, and others, later. 
(A)

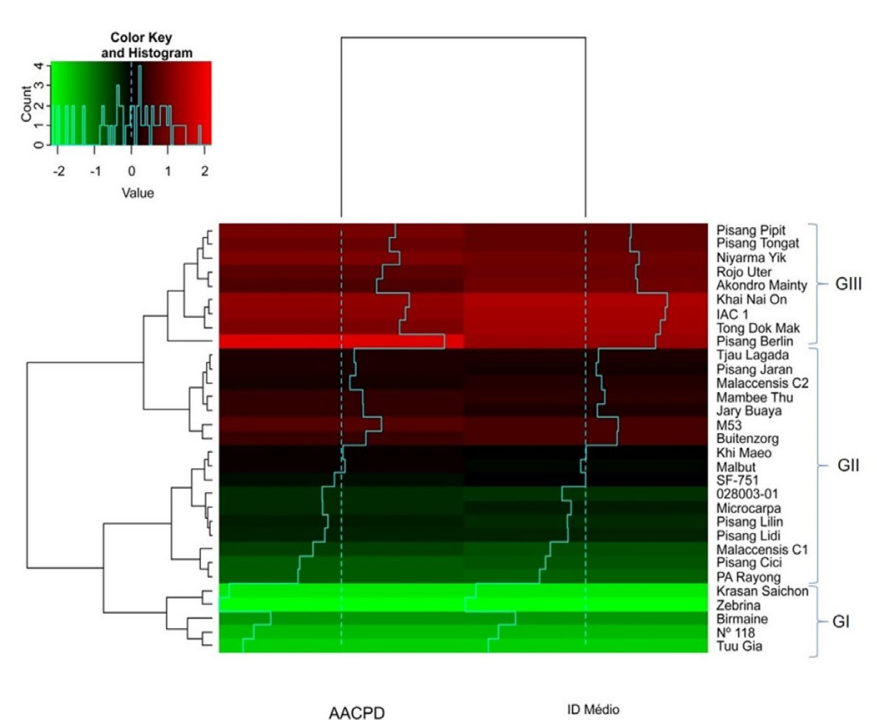

(B)

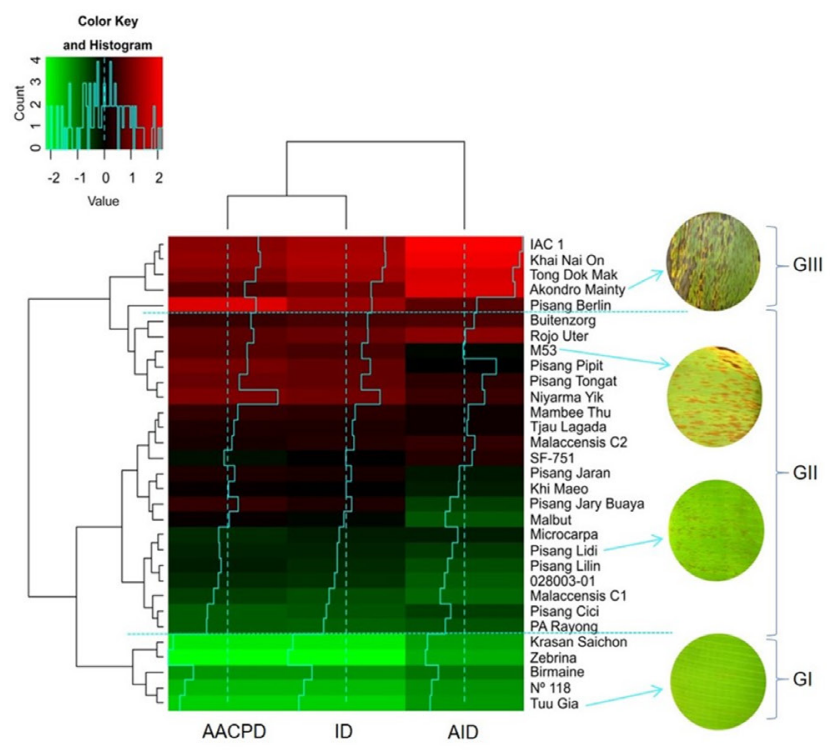

Figure 1. Hierarchical clustering between $\mathrm{AA}$ and $\mathrm{AB}$ banana diploids phenotyped for black Sigatoka resistance. (A) analysis based on two parameters: area under the disease progress curve (AUDPC) and disease severity index (DI); (B) analysis based on three parameters: AUDPC, DI, and DII. GI: resistant, GII: moderately resistant, GIII: susceptible. Cruz das Almas, BA, Embrapa 2020.

For some accessions, AUDPC and DI values were similar, being classified in the same resistance/ susceptibility profile. On the other hand, the DII analysis shows that some genotypes had less capacity to resist black Sigatoka infection because they were less efficient in activating resistance mechanisms. Therefore, it would not be correct to classify them all into the same group. For instance, Akondro Mainty (susceptible) and M53 (moderately resistant) accessions have both similar AUDPC and DI, but contrasting DII (Table 3). Akondro Mainty accession has been indicated as one of the possible ancestors of Prata and Cavendish subgroup cultivars, a fact that may justify the susceptibility of these genotypes to black Sigatoka (PERRIER et al., 2009; 2011; HIPOOLYTE et al., 2012; JESUS et al., 2013; CHRISTELOVÁ et al., 2016).

Two of the wild diploids classified as resistant are Tuu Gia and Birmanie; this information corroborates previous findings reported by Ortiz-Vázquez et al. (2005) and Rebouças et al. (2018). The other three accessions classified as resistant have no reports in the literature regarding black Sigatoka resistance/susceptibility. Likewise, Pisang Lilin, Pisang Lidi, and Tjau Lagada were identified as moderately resistant accessions, in agreement with results published by Leiva-Mora et al. (2015) and Silva et al. (2001). Among the susceptible ones, the genotype Niyarma Yik showed the same phenotyping result reported by Ferreira et al. (2004). Thus, the formed groups present reference genotypes, a fact that reinforces our phenotyping accuracy. It is important to highlight that $M$. fijiensis presents wide genetic variability regarding aggressiveness and virulence, requiring for that reason the local selection of resistant genotypes to avoid identification mistakes (ALAKONYA et al., 2018).

Table 3 shows the mean AUDPC, DI, and DII values, as well as the resistance levels of the phenotyped accessions in the presence of black Sigatoka under field conditions. The AUDPC ranged from 5.12 to 1089.19 , DI varied between 0.40 and 78.34 , and DII started at $0.04 \%$ and reached a maximum of $19.87 \%$. We cannot affirm that accessions with complete black Sigatoka resistance were identified in this study; however, we detected several genotypes with quantitative resistance, including those classified as resistant (Krasan Saichon, Zebrina, Birmanie, $\mathrm{N}^{\mathrm{o}} 118$, and Tuu Gia) and moderately resistant, which were further subjected to a more careful selection.

The Scott-Knott cluster test was used to compare the accessions classified as moderately resistant (Table 4), and genotypes clustering as a function of three variables was performed. Based on the proposed SI cutoff point $(\leq 70)$, it is possible to state that accessions PA Rayong, Pisang Cici, Malaccensis 1, 028003-01, Microcarpa, Pisang Lidi, Lilin, and Malbut are good genotypes to be used in future crosses, since, improved diploids with durable quantitative black Sigatoka resistance could be developed from them. 
Table 3. Area under the disease progress curve (AUDPC), disease severity index (DI), and disease severity increase index (DII) in banana diploid accessions belonging to the Embrapa banana and plantain germplasm collection phenotyped in the presence of black Sigatoka. Cruz das Almas, BA, Embrapa 2020.

\begin{tabular}{|c|c|c|c|c|}
\hline Genotype & AUDPC & DI (\%) & DII (\%) & LR \\
\hline Pisang Berlin & 1089,19 & 73,88 & 12,07 & $\mathrm{~S}$ \\
\hline IAC 1 & 899,654 & 77,46 & 19,87 & $\mathrm{~S}$ \\
\hline Khai Nai On & 917,82 & 78,34 & 19,22 & $\mathrm{~S}$ \\
\hline Tong Dok Mak & 871,52 & 75,70 & 17,89 & $\mathrm{~S}$ \\
\hline Akondro Mainty & 763,28 & 66,71 & 18,31 & $\mathrm{~S}$ \\
\hline Niyarma Yik & 872,97 & 67,48 & 10,52 & MR \\
\hline Pisang Tongat & 824,65 & 63,84 & 9,94 & MR \\
\hline Pisang Pipit & 852,84 & 64,32 & 8,08 & MR \\
\hline M53 & 784,49 & 59,44 & 7,70 & MR \\
\hline Rojo Uter & 789,17 & 66,17 & 14,50 & MR \\
\hline Buitenzorg & 710,81 & 59,01 & 11,62 & MR \\
\hline Mambee Thu & 695,38 & 54,21 & 8,75 & MR \\
\hline Tjau Lagada & 653,80 & 51,80 & 8,53 & MR \\
\hline Malaccensis 2 & 634,68 & 53,08 & 10,10 & MR \\
\hline SF-751 & 558,32 & 46,76 & 9,57 & MR \\
\hline Pisang Jaran & 661,86 & 50,96 & 6,94 & MR \\
\hline Khi Maeo & 600,90 & 46,93 & 6,78 & MR \\
\hline Pisang Jari Buaya & 698,16 & 51,39 & 5,03 & MR \\
\hline Malbut & 610,09 & 45,03 & 4,10 & MR \\
\hline Microcarpa & 503,37 & 41,29 & 6,64 & MR \\
\hline Pisang Lidi & 512,28 & 39,97 & 5,50 & MR \\
\hline Pisang Lillin & 527,17 & 39,72 & 4,53 & MR \\
\hline 028003-01 & 500,73 & 37,62 & 3,93 & MR \\
\hline Malaccensis 1 & 455,61 & 33,24 & 3,08 & MR \\
\hline Pisang Cici & 391,52 & 31,23 & 5,20 & MR \\
\hline PA Rayong & 383,72 & 29,12 & 4,05 & MR \\
\hline Krasan Saichon & 53,87 & 4,48 & 0,45 & $\mathrm{R}$ \\
\hline Zebrina & 5,12 & 0,40 & 0,04 & $\mathrm{R}$ \\
\hline Birmanie & 252,80 & 19,79 & 2,61 & $\mathrm{R}$ \\
\hline $\mathrm{N}^{\mathrm{o}} 118$ & 170,85 & 13,18 & 1,28 & $\mathrm{R}$ \\
\hline Tuu Gia & 118,97 & 9,33 & 0,97 & $\mathrm{R}$ \\
\hline
\end{tabular}

LR: level of resistance; S: susceptible; MR: moderately resistant; R: resistant. 
Table 4. Grouping of genotypes based on the mean area under the disease progress curve (AUDPC), disease severity index (DI), disease severity increase index (DII), and selection index (SI) in banana diploid accessions belonging to the Embrapa banana and plantain germplasm collection classified as moderately resistant to black Sigatoka. Cruz das Almas, BA, Embrapa 2020.

\begin{tabular}{lllrl}
\hline Genotypes & AUDPC & DI & DII & SI \\
\hline Rojo Uter & $789,17 \mathrm{a}$ & $66,17 \mathrm{a}$ & $14,50 \mathrm{a}$ & 170 \\
Pisang Tongat & $824,65 \mathrm{a}$ & $63,84 \mathrm{a}$ & $9,94 \mathrm{c}$ & 150 \\
Niyarma Yik & $872,97 \mathrm{a}$ & $67,48 \mathrm{a}$ & $10,52 \mathrm{c}$ & 150 \\
Pisang Pipit & $852,84 \mathrm{a}$ & $64,32 \mathrm{a}$ & $8,08 \mathrm{~d}$ & 140 \\
Buitenzorg & $710,81 \mathrm{~b}$ & $59,01 \mathrm{~b}$ & $11,62 \mathrm{~b}$ & 140 \\
M53 & $784,49 \mathrm{a}$ & $59,44 \mathrm{~b}$ & $7,70 \mathrm{~d}$ & 130 \\
Malaccensis 2 & $634,68 \mathrm{~b}$ & $53,08 \mathrm{c}$ & $10,10 \mathrm{c}$ & 120 \\
Tjau Lagada & $653,80 \mathrm{~b}$ & $51,80 \mathrm{c}$ & $8,53 \mathrm{~d}$ & 110 \\
Mambee Thu & $695,38 \mathrm{~b}$ & $54,21 \mathrm{c}$ & $8,75 \mathrm{~d}$ & 110 \\
SF- 751 & $558,32 \mathrm{c}$ & $46,76 \mathrm{~d}$ & $9,57 \mathrm{c}$ & 100 \\
Pisang Jaran & $661,86 \mathrm{~b}$ & $50,96 \mathrm{c}$ & $6,94 \mathrm{e}$ & 100 \\
Jari Buaya & $698,16 \mathrm{~b}$ & $51,39 \mathrm{c}$ & $5,03 \mathrm{f}$ & 90 \\
Khi Maeo & $600,90 \mathrm{c}$ & $46,93 \mathrm{~d}$ & $6,78 \mathrm{e}$ & 80 \\
Pisang Lidi & $512,28 \mathrm{c}$ & $39,97 \mathrm{e}$ & $5,50 \mathrm{e}$ & 70 \\
Microcarpa & $503,37 \mathrm{c}$ & $41,29 \mathrm{e}$ & $6,64 \mathrm{e}$ & 70 \\
Pisang Lilin & $527,17 \mathrm{c}$ & $39,72 \mathrm{e}$ & $4,53 \mathrm{f}$ & 60 \\
Malbut & $610,09 \mathrm{c}$ & $45,03 \mathrm{~d}$ & $4,10 \mathrm{~g}$ & 60 \\
028003-01 & $500,73 \mathrm{c}$ & $37,62 \mathrm{e}$ & $3,93 \mathrm{~g}$ & 50 \\
Pisang Cici & $391,52 \mathrm{~d}$ & $31,23 \mathrm{f}$ & $5,20 \mathrm{f}$ & 40 \\
PA Rayong & $383,72 \mathrm{~d}$ & $29,12 \mathrm{f}$ & $4,05 \mathrm{~g}$ & 30 \\
Malaccensis 1 & $455,61 \mathrm{~d}$ & $33,24 \mathrm{f}$ & $3,08 \mathrm{~g}$ & 30 \\
\hline
\end{tabular}

Averages with the same letter, in the column, form clusters based on the method of Scott and Knott, at 5\% probability.

Tuu Gia, Birmanie, Zebrina, PA Rayong, and Pisang Lilin accessions were considered resistant to F. oxysporum f. sp. cubense (Foc) tropical race 4, a quarantine pest not present in Brazil (ZUO et al., 2018). Birmanie, Malaccensis 1, and 028003-01 were classified as resistant to Foc race 1 in two other studies (REBOUÇAS et al. 2018; RIBEIRO et al., 2018). Based on this information, the intercrossing between these accessions may allow the selection of hybrid progenies resistant to Foc and black Sigatoka.

Craenen and Ortiz (1997) did not report complete resistance to $M$. fijiensis, although some resistance levels were clearly demonstrated. Such results were corroborated in the present study since no accessions free of disease signs could be identified in the field. On the other hand, Gonçalves (2019) phenotyped improved diploids in the presence of black Sigatoka and identified complete resistance in three hybrids. According to this author, the accumulation of resistance genes derived from the parents of these diploids would explain this finding.
The phenotypic survey conducted in this research has relevant implications for genotype screenings targeted to black Sigatoka resistance because it suggests that the use of the DII and SI, formulated here as two additional tools, may allow a more accurate genotype classification and prevent the loss of genes of interest. This is very important considering that most genotypes have polygenic resistance, and possible genetic background effects can reduce the efficiency of assisted selection programs. Our experimental data show variability for black Sigatoka resistance among the available banana diploid accessions evaluated; the genotypes considered resistant or moderately resistant can be used as parents to generate improved diploids for gene introgression in new cultivars. 


\section{Conclusions}

The parameter DII has a better ability to stratify banana accessions than other parameters usually employed, representing a new approach for the identification of resistant genotypes. This was validated in this study, the first one to select black Sigatoka resistant diploid genotypes in Bahia, Brazil. We identified five banana diploid accessions resistant to black Sigatoka (Krasan Saichon, Zebrina, Birmanie, $N^{\circ} 118$, and Tuu Gia) and eight moderately resistant accessions (PA Rayong, Pisang Cici, Malaccensis 1, 028003-01, Microcarpa, Pisang Lidi, Lilin, and Malbut).

\section{Acknowledgments}

We thank FAPESB for the master's scholarship granted to the rst author, the Breeding Better Bananas/ IITA/Bill and Melinda Gates Foundation project, The Brazilian National Council for Scientific and Technological Development (CNPq, Process number 306648/2018-0) and the Embrapa Mandioca e Fruticultura team for providing us with the facilities to conduct this study.

\section{References}

AGRITEMPO. Agritempo: sistema de monitoramento agrometeorológico. Disponível em: http://www.agritempo. gov.br/agroclima/sumario. Acesso em: 13 dez. 2018.

ALAKONYA, A.E.; KIMUNYEB, J.; MAHUKUC, G.; AMAHA, D.; UWIMANAB, B.; BROWND, A.SWENNEND, R. Progress in understanding Pseudocercospora banana pathogens and the development of resistant Musa germplasm. Plant Pathology, Oxford, v.67, n.4, p.759-770, 2018.

AMORIM, E.P.; SANTOS-SEREJO, J.A.; AMORIM, V.B.O.; FERREIRA, C.F.; SILVA, S. Banana breeding at Embrapa cassava and fruits. Acta Horticulturae, The Hague, n.986, p.171-176, 2013.

BURGOS-CANUL, Y.Y.; CANTO-CANCHÉ, B.; BEREZOVSKI, M.V.; MIRONOV,G.; LOYOLAVARGAS, V.M.; ROSA, A.P.B.; TZEC-SIMÁ, M.; BRITO-ARGÁEZ, L.; CARRILLO-PECH, M.; GRIJALVA-ARANGO, R.; MUÑOZ-PÉREZ, G.; ISLAS-FLORES, I. The cell wall proteome from two strains of Pseudocercospora fijiensis with differences in virulence. World Journal of Microbiology and Biotechnology, Dordrecht, v.35, n.7, p.105, 2019.
CHARRAD, M.; GHAZZALI, N.; BOITEAU, V.; NIKNAFS, A.; CHARRAD, M.M. Package 'nbclust'. Journal of statistical software, Los Angeles, v.61, p.136, 2014.

CHRISTELOVÁ, P.; DE LANGHE, E.; HŘIBOVÁ, E.; ČÍŽKOVÁ, J.; SARDOS, J.; HUŠÁKOVÁ, M.; HOUVE, I.V.D.; SUTANTO, A., KEPLER, A.K., SWENNEN, R., ROUX, N., DOLEŽEL, J. Molecular and cytological characterization of the global Musa germplasm collection provides insights in to the treasure of banana diversity. Biodiversity and Conservation, Madrid, v.26, n.4, p.801-824, 2016.

CHURCHILL, A.C.L. Mycosphaerella fijiensis, the black leaf streak pathogen of banana: progress towards understanding pathogen biology and detection, disease development, and the challenges of control. Molecular Plant Pathology, Bristol, v.12, n.4, p.307-328, 2011.

CRAENEN, K.; ORTIZ, R. Effect of the bs1 gene in plantain-banana hybrids on response to black Sigatoka. Theoretical and Applied Genetics, Berlin, v.95, n.3, p.497-505, 1997.

CROUS, P.W.; GROENEWALED, J.Z.; APTROOT, A.; BRAUN, U.X.; CARLIER, J. Integrating morphological and molecular data sets on Mycosphaerella, with specific reference to species occurring on Musa. In: WORKSHOP ON MYCOSPHAERELLA LEAF SPOT DISEASES, 2002 may 20-23, San José. Proceedings [...] San José: The International Network for the Improvement of Banana and Plantain, 2003. p.43-57.

DIAZ-TRUJILLO, C.; CHONG, P.; STERGIOPOULOS, I.; CORDOVEZ, V.; GUZMAN, M.; WIT, P.J.G.M.; MEIJER, H.J.G.; SCALLIET, G.; SIEROTZKI, H.; PERALTA, E.L; ISAZA, R.E.A.; KEMA, G.H.J. A new mechanism for reduced sensitivity to demethylationinhibitor fungicides in the fungal banana black Sigatoka pathogen Pseudocercospora fijiensis. Molecular Plant Pathology, Bristol, v.19, n.6, p.1491-1503, 2018.

FERREIRA,C.F.; SILVA,S.O.; SOBRINHO, N.P.D.; DAMASCENA, S.C.S.; ASSIS, F.S.; ALVES, A.O.; PAZ, O.P. Molecular Characterization of banana (AA) diploids with contrasting levels of black and yellow sigatoka resistance. American Journal of Applied Sciences, Ellicott City, v.1, n.4, p.276-278, 2004.

GAUHL, F. Untersuchungen zur Epidemiologie und Ökologie der Schwarzen Sigatoka-Krankheit (Mycosphaerella fijiensis Morelet) an Kochbananen (Musa sp.) in Costa Rica. 1989. Thesis(PhD) - University of Göttingen, Göttingen, 1989. 
GASPAROTTO, L.; PEREIRA, J.C.R.; HANADA, R.E.; MONTARRYOS, A.V.V. Sigatoka negra da bananeira. Manaus: Embrapa, 2006.

GONÇALVES, Z.S. Fontes de resistência à murcha de Fusarium raça 1 e Sigatoka-negra entre híbridos de bananeira. 2019. Tese (Doutorado em Biotecnologia) - Universidade Estadual de Feira de Santana, Feira de Santana, 2019.

HIPPOLYTE, I.; JENNY, C.; GARDES, L.; BAKRY, F.; RIVALLAN, R.; POMIES, V.; CUBRY, P.; TOMEKPE, K.; RISTERUCCI, A.M.; ROUX, N.; ROUARD, M.; ARNAUD, E.; KOLESNIKOVA-ALLEN, M.; PERRIER, $\mathrm{X}$. Foundation characteristics of edible Musa triploids revealed from allelic distribution of SSR markers. Annals of Botany, Oxford, v.109, n.5, p.937-951, 2012.

JESUS, O.N.; SILVA, S.O.; AMORIM, E.P.; FERREIRA, C.F.; CAMPOS, J.M.S.; SILVA, G.G.; FIGUEIRA, A. Genetic diversity and population structure of Musa accessions in ex situ conservation. BMC Plant Biology, London, v.13, n.41, p.22, 2013.

JIMENEZ, M.I.; VAN DER VEKEN, L.; NEIRYNCK, H.; RODRIGUEZ, H.; RUIZ, O.SWENNEN, R. Organic banana production in Ecuador: its implications on black Sigatoka development and plant-soil nutritional status. Renewable Agriculture \& Food Systems, Cambridge, v.22, n.4, p.297-306, 2007.

JONES, R.D. Sigatoka leaf spots. In: JONES, R.D. (Ed.). Disease of banana, abaca and enset. Wallingford: CABI Publishing, 2000. p.79-92.

KRZANOWSKI, W.J.; LAI, Y.T. A Criterion for determining the number of groups in a data set using sum-of-squares clustering. Biometrics, New York, v.44, n.1, p.23-34, 1988. (1)

LEIVA-MORA, M.; ALVARADO-CAPÓ, Y.; ACOSTASUÁREZ, M.; CRUZ-MARTÍN, M.; ROQUE, B.; MÉNDEZ, E.M. Components of resistance to assess Black Sigatoka response in artificially inoculated Musa genotypes. Revista de Protección Vegetal, San José de las Lajas, v.30, n.1, p.60-69, 2015.

MADDEN, L.V.; HUGLES, G.; BOSCH, F.V.D. The study of plant disease epidemics. St Paul: APS Press, 2007.

MCKINNEY, R.H. Influence of soil temperature and moisture on infection of wheat seedlings by Helminthosporium sativum. Journal of Agricultural Research, Washington, v.6, p.195-218, 1923.
ONYILO, F.; TUSIIME, G.; TRIPATHI, J.N.; CHEN, L.H.; FALK, B.; STERGIOPOULOS, L.; TUSHEMEREIRWE, W.; KUBIRIBA, J.; TRIPATHI, L. Silencing of the mitogen-activated protein kinases (MAPK) Fus3 and Slt2 in Pseudocercospora fijiensis reduces growth and virulence on host plants. Frontiers in Plant Science, Lausanne, v.9, p.291, 2018.

ORTIZ, R.; VUYLSTEKE D. Inheritance of black Sigatoka resistance in plantain and banana (Musa spp.) hybrids. Theoretical and Applied Genetics, Berlin, v.89, n.2-3, p.146-152, 1994.

ORTIZ-VÁZQUEZ, E.; KAEMMER, D.; ZHANG, H.B.; MUTH, J.; RODRÍGUEZ-MENDIOLA, M.; ARIAS-CASTRO, C.; JAMES, A. Construction and characterization of a plant transformation-competent BIBAC library of the black Sigatoka-resistant banana Musa acuminata cv.Tuu Gia (AA). Theoretical and Applied Genetics, Berlin, v.110, n.4, p.706-713, 2005.

PERRIER, X.; BAKRY, F.; CARREEL, F.; JENNY, C.; HORRY, J.P.; LEBOT, V.; HIPPOLYTE, I. Combining biological approaches to shed light on the evolution of edible bananas. Ethnobotany Research \& Applications, Tbilisi, v.7, p.199-216, 2009.

PERRIER, X.; DE LANGHE, E.; DONOHUE, M.; LENTFER, C.; VRYDAGHS, L.; BAKRY, F. Multidisciplinary perspectives on banana (Musa spp.) domestication. Proceedings of the National Academy of Sciences of the United States of America, Washington, v.108, n.28, p.11311-11318, 2011.

REBOUÇAS, T.A.; HADDAD, F.; FERREIRA, C.F.; OLIVEIRA, S.A.S.; LEDO, C.A.S.; AMORIM, E.P. Identification of banana genotypes resistant to Fusarium wilt race 1 under field and greenhouse conditions. Scientia Horticulturae, New York, v.239, p.308-313, 2018.

RIBEIRO, L.R.; SILVA, S.O.E; OLIVEIRA, S.A.S.; AMORIM, E.P.; SEREJO, J.A.S.; HADDAD, F. Sources of resistance to Fusarium oxysporum f.sp.cubense in banana germplasm. Revista Brasileira de Fruticultura, Jaboticabal, v.40, n.1, 2018.

SILVA, S.O.; SOUZA JUNIOR, M.T.; ALVES,E.J.; SILVEIRA, J.R.S.; LIMA, M.B. Banana breeding program at Embrapa. Crop Breeding and Applied Biotechnology, Lavras, v.1, n.4, p.399-436, 2001.

STOVER, R.H. Banana plantain and abaca diseases. Toronto: Commonwelth Mycological Institute, 1972. p.316. 
WARNES, G.R.; BOLKER, B.; BONEBAKKER, L.; GENTLEMAN, R.; LIAW, W.H.A.; LUMLEY, T. Gplots: various R programming tools for plotting data. 2015. Available from: https://www.scienceopen.com/ document?vid=0e5d8e31-1fe4-492f-a3d8-8cd71b2b8ad9.

WEBER, O.B.; GARRUTI, D.S.; NORÕES, N.P.; SILVA, S.O.E. Performance of banana genotypes with resistance to black leaf streak disease in Northeastern Brazil. Pesquisa Agropecuária Brasileira, Brasília, DF, v.52, n.3, p.161-169, 2017.
WICKHAM, H.; CHANG, W. Devtools: tools to make developing $\mathrm{R}$ packages easier. R package version 1.13.4. 2017. Available from: https://rdrr.io/cran/devtools./

ZUO, C.; DENG, G.; LI, B.; HUO, H.; LI, C.; HU, C.; KUANG, R.; YANG, Q.; DONG, T.; SHENG, O.; YI, G. Germplasm screening of Musa spp. for resistance to Fusarium oxysporum f. sp. cubense tropical race 4 (Foc TR4). European Journal of Plant Pathology, Dordrecht, v. 151, n.3, p. 723-734, 2018. 